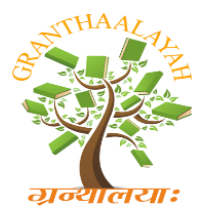

$$
\begin{gathered}
\text { INTERNATIONAL JOURNAL OF RESEARCH - } \\
\text { GRANTHAALAYAH } \\
\text { A knowledge Repository }
\end{gathered}
$$

Management

\title{
THE IMPACT OF SELF-HELP GROUPS ON THE SOCIO-ECONOMIC DEVELOPMENT OF RURAL HOUSEHOLD WOMEN IN TAMIL NADU - A STUDY
}

\author{
M. Saravanan ${ }^{* 1}$ \\ ${ }^{* 1} \mathrm{PhD}$ Research Scholar (Part-time), Department of Economics, Pachayappa's College, \\ Chennai- 600 035, INDIA
}

DOI: https://doi.org/10.29121/granthaalayah.v4.i7(SE).2016.2624

\begin{abstract}
Women empowerment is a process in which women challenge the existing norms and cultural, to effectively promote their well-being. The participation of women in self-help group (SHGs) made a significant impact on their empowerment both in social and economic aspects this study addresses women empowerment through self-help groups in TamilNadu. The information required for the study has been collected from only secondary sources has been followed full paper. The SHGs have had greater impact on both economic and social aspects of the beneficiaries.
\end{abstract}

Keywords:

Woman empowerment, SHG Movement, Socio-economic development, Tamilnadu.

Cite This Article: M. Saravanan, "THE IMPACT OF SELF-HELP GROUPS ON THE SOCIOECONOMIC DEVELOPMENT OF RURAL HOUSEHOLD WOMEN IN TAMIL NADU - A STUDY" International Journal of Research - Granthaalayah, Vol. 4, No. 7: SE (2016): 22-31.

\section{INTRODUCTION}

Self-Help Group or in-short SHGs is now a well-known concept. It is now almost two decade old. Self-help groups (SHGs) play today a major role in poverty alleviation in rural area. It is reported that the SHGs have a role in hastening country's economic Development. SHGs have now evolved as a movement. Mainly, members of the SHGs are women. Consequently, participation of women in the country's economic development is increasing. They also play an important role in elevating the economic status of their families. Women constitute around fifty percent of the total human resources in our economy. This has led to boost the process of women's Empowerment. Yet women are subservient to men as they are subject to many socioeconomic and cultural constraints. The situation is more severe in the rural and backward areas. Women development activities must be given importance to eradicate poverty, increase the economic growth and for better standard of living. The SHG promotes small savings among its 
members. Self-Help Group (SHG) is a small voluntary association of poor people, preferably from the same socio-economic background. This paper attempts to identity the role of SHGs in providing income and saving to rural poor household in Tamil Nadu.

\section{OBJECTIVES OF SHGs}

- To examine the role of SHG in developing socio economic status of rural women

- To alleviate rural poverty and increase employment opportunity

- To promote income generating activities in rural household women

\section{METHODOLOGY}

The present paper is primarily based on secondary sources of data. Present study focus on Tamil Nadu self-help group's impact and movement. Secondary data were collected from Tamil Nadu Corporation for Development of Women (TNCDW), Annual reports, the statistical supplements, and operational statistics of Tamil Nadu State, Government Website, Published sources include Government publications, and other publications like research articles published in journal available.

\section{ORIGIN OF SHGS}

The origin of Self Help Groups (SHGs) is the brainchild of Grameen Bank of Bangaladesh, founded by Prof. Mohammed Yunus in 1975, who tried out a new approach to rural credit in Bangaladesh. Grameen gave loans without asking borrowers either to provide collateral or engage in paper work. In India NABARD initiated SHGs in the year 1986-87 but the real effort was taken after 1991-92 from the linkage of SHGs with the banks. A SHG is a small economically homogeneous affinity group of the rural poor voluntarily coming forward to save a small amount of money regularly, which is deposited in a common fund to meet the members ${ }^{\text {ee }}$ emergency needs and to provide collateral free loans decided by the group. It now addresses the issues of poverty alleviation and empowerment of poor, health, nutrition and other support services especially women, in the rural areas of the country.

\section{CONCEPT AND FUNCTION OF SELF-HELP GROUPS}

Generally Self-Help Group consists of 10 to 20 women. The women save some amount that they can afford. It is small amount ranging from Rs. 10 to 200 per month. A monthly meeting is organized, where apart from disbursal \& repayment of loan, formal and informal discussions are held. Women share their experiences in these groups. The minutes of these meetings are documented and the accounts are written. The President, Secretary and Treasurer are three official posts in any SHG. If the SHGs are connected with some NGOs, they take part in other social activities of those NGOs. Of late, the organizational structure of various micro-financial groups is undergoing significant changes. There are Thrift groups, Credit management groups, Income generating groups, Self-help groups and Mutual help groups. Sometimes the institute that promotes the SHG, itself provides loan facilities. It is called as Micro-finance Institute. All households are living under 'Below Poverty Line' category and their income is less than Rs. 40,000 per year. The National Bank for Agriculture \&Rural Development will create an Rs.15 
billion fund to cater to women's Self-Help Groups in economically weaker districts in the country, after joining the self-help group the women are economically and socially empowered. It is especially focus on the SC/ST.

\section{SELF - HELP GROUPS IN INDIAN MOVEMENT}

India has adopted the Bangladesh's model in a modified form. To alleviate the poverty and to empower the women, the micro-finance has emerged as a powerful instrument in the new economy. With availability of micro-finance, self-help groups (SHGs) and credit management groups have also started in India. And thus the movement of SHG has spread out in India. Table shows.

Table 1: State -wise spread of the SHG-Bank Linkage programme

\begin{tabular}{|c|c|c|c|c|}
\hline States & SHGs & $\begin{array}{l}\text { Savings } \\
\text { (in lakhs) }\end{array}$ & $\begin{array}{l}\text { \% of } \\
\text { SHGs }\end{array}$ & $\begin{array}{l}\% \text { of } \\
\text { savings }\end{array}$ \\
\hline Andhra Pradesh & 1418676 & 349962.18 & 19.09 & 35.36 \\
\hline Arunachal Pradesh & 2588 & 153.01 & 0.034 & 0.02 \\
\hline Assam & 285327 & 11289.51 & 3.84 & 1.14 \\
\hline Bihar & 268721 & 16466.57 & 3.62 & 1.66 \\
\hline Chhattisgarh & 11184 & 18283.52 & 1.51 & 1.85 \\
\hline Goa & 8170 & 1313.37 & 0.11 & 0.13 \\
\hline Gujarat & 196510 & 16872.00 & 2.64 & 1.70 \\
\hline Haryana & 43029 & 4539.47 & 0.58 & 0.46 \\
\hline Himachal Pradesh & 37634 & 2732.43 & 0.51 & 0.28 \\
\hline Jammu\& Kashmir & 873 & 40.74 & 0.01 & 0.004 \\
\hline Jharkhand & 86386 & 8932.95 & 1.16 & 0.90 \\
\hline Karnataka & 709171 & 108757.29 & 9.55 & 10.98 \\
\hline Kerala & 601325 & 56942.49 & 8.09 & 5.75 \\
\hline Madhya Pradesh & 157481 & 13010.41 & 2.12 & 1.31 \\
\hline Maharashtra & 692274 & 74805.53 & 9.32 & 7.56 \\
\hline Manipur & 9039 & 94.92 & 0.12 & 0.009 \\
\hline Meghalaya & 7230 & 536.65 & 0.10 & 0.04 \\
\hline Mizoram & 187 & 4.46 & 0.002 & 0.00 \\
\hline Nagaland & 2437 & 210.08 & 0.03 & 0.021 \\
\hline New Delhi & 2901 & 660.57 & 0.04 & 0.06 \\
\hline Odisha & 517391 & 45733.95 & 6.96 & 4.62 \\
\hline Punjab & 23041 & 2283.98 & 0.31 & 0.23 \\
\hline Rajasthan & 257262 & 17906.61 & 3.46 & 1.80 \\
\hline Sikkim & 343 & 35.49 & 0.004 & 0.00 \\
\hline Tamil Nadu & 942469 & 105145.21 & 12.69 & 10.62 \\
\hline Tripura & 9148 & 558.00 & 0.12 & 0.06 \\
\hline Uttar Pradesh & 379270 & 43858.84 & 5.10 & 4.43 \\
\hline Uttarkhand & 37294 & 3903.04 & 0.50 & 0.39 \\
\hline West Bengal & 591464 & 81406.51 & 7.96 & 8.23 \\
\hline A \&N Islands & 4824 & 115.58 & 0.06 & 0.01 \\
\hline
\end{tabular}




\begin{tabular}{|l|l|l|l|l|}
\hline Puducherry & 24454 & 2406.41 & 0.33 & 0.24 \\
\hline Chandigarh & 468 & 13096 & 0.01 & 1.32 \\
\hline Lakshadweep & 229 & 648.81 & 0.003 & 0.07 \\
\hline Total & 7429500 & 989741.54 & 100 & 100 \\
\hline
\end{tabular}

Source: NABARD: Status of Micro Finance in India 2013-14

The allocation of funds for the SGSY scheme by both central and statese governments was Rs.1, $472 \mathrm{cr}$. in $1999-00$, the first year of the program. The total amount allocated for the program during 10 years is Rs.14, 467 cr. It is less than half of the budgetary allocation of Rs.30, $100 \mathrm{cr}$. for NREG in just one year, i.e. 2009 - 10. The principal reason for stagnation in funds allocation is non-cooperation of banks. The allocated meager amounts were not fully utilized even in one year during the last 10 years program period. Total utilization is $74 \%$ of funds made available as a result the program is often known as subsidy oriented program.

In India, Aim of the SHGs is to give social empowerment to women. In 1991-92 NABARD started promoting self-help groups on a large scale. And it was the real take-off point for the 'SHG movement'. In 1993, the Reserve Bank of India also allowed SHGs to open saving accounts in banks. State wise linkage programmed loan scheme and saving amount show the table.

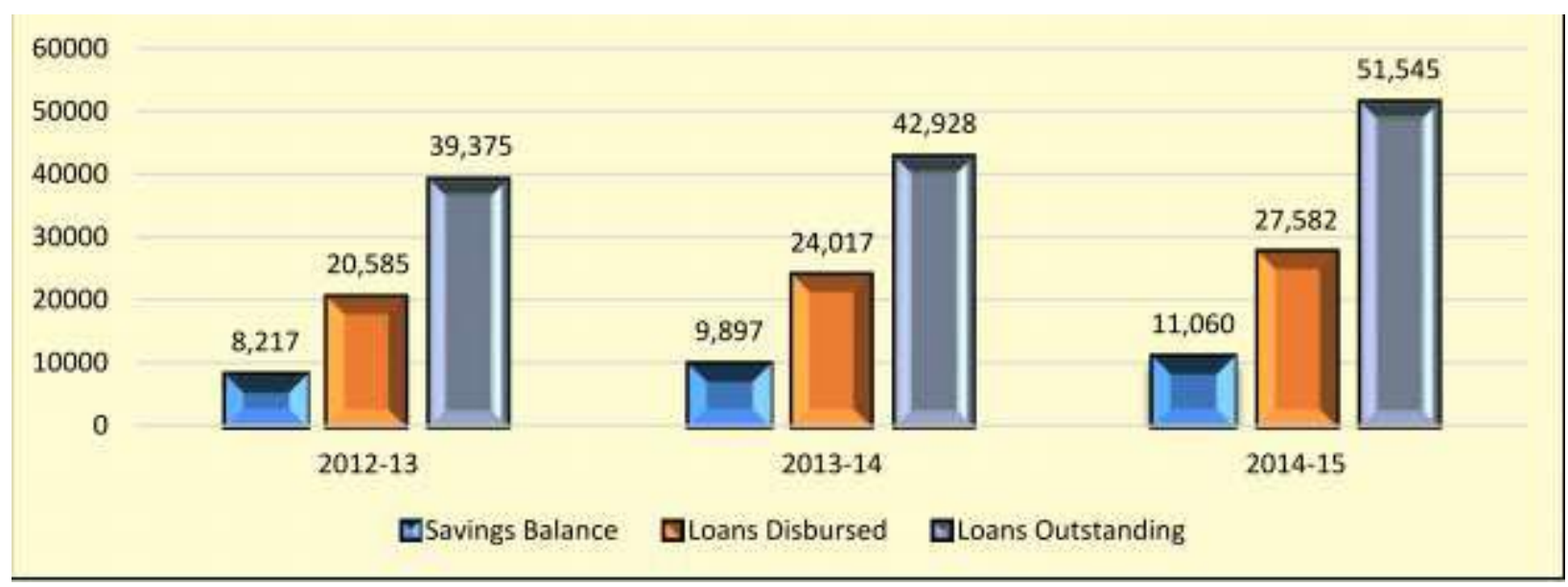

Source: Status of Microfinance in India report, 2014-15, NABARD

Figure 1: SHG-Bank Linkage Highlights (crores)

Self-help groups (SHGs) play today a major role in poverty alleviation in rural India. A growing number of poor people (mostly women) in various parts of India are members of SHGs and actively engage in savings and credit, as well as in other activities (income generation, natural resources management, literacy, child care and nutrition, etc.). The S/C focus in the SHG is the most prominent element and offers a chance to create some control over capital. Empowerment of the poor encompasses three basic dimensions-reduction of poverty, creation of employment, and erasing inequality. The self-help group approach in India has taken strong roots as an effective and viable channel to take the poor to a new domain of economic empowerment and social upliftment. India is poised to provide pragmatic solutions by demonstrating the success of micro finance for eliminating total poverty in the coming decade. Now nearly 560 banks like and 
more than 3,024 NGOs are collectively and actively involved in the promotion of SHG movement.

\section{SELF -HELP GROUPS MOVEMENT IN TAMIL NADU}

Tamil Nadu is the 11th largest state in India and spread over 1, 30,000 sq kms. It has 35 million female in its total population of 72 million in 2011. This was taken not only as a social welfare group but also a centre for economic improvement of women. Hence the concept of "Women Groups for Self Employed" emerged in Tamil Nadu. It was called "Mahalir Sangam" or Mahalir Kuzhu" or Mahalir Mandram. The status of self-help group below show the table.

Table 2: Status of SHGs in Tamil Nadu (2014)

\begin{tabular}{|c|c|c|c|c|}
\hline SL No & District & Groups formed & Women enrolled & Saving (Rs lakhs) \\
\hline 1 & Ariyalur & 6708 & 106969 & 3527.14 \\
\hline 2 & Chennai & 23620 & 366110 & 9948.75 \\
\hline 3 & Coimbatore & 14879 & 235545 & 8525.18 \\
\hline 4 & Cuddalore & 17705 & 281372 & 10294.39 \\
\hline 5 & Dharmapuri & 8005 & 127481 & 7247.89 \\
\hline 6 & Dindigul & 13569 & 215707 & 4950 \\
\hline 7 & Erode & 15431 & 243908 & 8944.75 \\
\hline 8 & Kancheepuram & 23491 & 372339 & 13087.07 \\
\hline 9 & Kanniyakumari & 14129 & 222067 & 11918.2 \\
\hline 10 & Karur & 9750 & 154849 & 11826.2 \\
\hline 11 & Krihnagiri & 9911 & 157964 & 8792.5 \\
\hline 12 & Madurai & 14420 & 228363 & 8513.81 \\
\hline 13 & Nagapattinam & 13608 & 216620 & 8930.45 \\
\hline 14 & Namakkal & 11818 & 187382 & 8935.25 \\
\hline 15 & Nilgiris & 7266 & 114378 & 4238.7 \\
\hline 16 & Perambalur & 4016 & 63975 & 952.4 \\
\hline 17 & Pudukkottai & 11324 & 180438 & 21450.02 \\
\hline 18 & Ramnad & 9928 & 157893 & 8086.58 \\
\hline 19 & Salem & 18464 & 291668 & 7167.5 \\
\hline 20 & Sivagangai & 10333 & 164582 & 5883.7 \\
\hline 21 & Thiruvannamalai & 17647 & 280945 & 5208 \\
\hline 22 & Thirunelveli & 18985 & 300162 & 9859.6 \\
\hline 23 & Thanjavur & 17308 & 274981 & 10102.1 \\
\hline 24 & Theni & 10960 & 173080 & 5228.05 \\
\hline 25 & Thiruvallur & 16728 & 264564 & 8400.98 \\
\hline 26 & Thiruvarur & 10919 & 173884 & 4224.74 \\
\hline 27 & Thirupur & 11752 & 185672 & 7191.96 \\
\hline 28 & Thoothikudi & 15038 & 238487 & 7514.74 \\
\hline 29 & Thrichy & 15330 & 242822 & 5962.94 \\
\hline 30 & Vellore & 16488 & 262390 & 9358.56 \\
\hline 31 & Villupuram & 19529 & 311120 & 5075.45 \\
\hline 32 & Virudhunager & 12250 & 194589 & 5453.39 \\
\hline
\end{tabular}




\begin{tabular}{|l|l|l|l|l|}
\hline & Total & 441311 & 6991366 & 256800.99 \\
\hline
\end{tabular}

Source: www, tnwomser development corporation.org

The group should have limited number of members which will be congenial to the successful functioning. In this regard it will be appropriate to have 15 to 20 members. The member will be benefited by having free, track and open discussions before arriving at any decision regarding the execution of the different activities of the groups. The groups can function effectively and successfully by consulting each other and sharing of thoughts through periodical meetings at the particular place. The attendance register and the recorded minute's book will expose the group solidarity of the member.

Table 3: SHGs Which Received Bank Loan in Tamil Nadu (2010-2014)

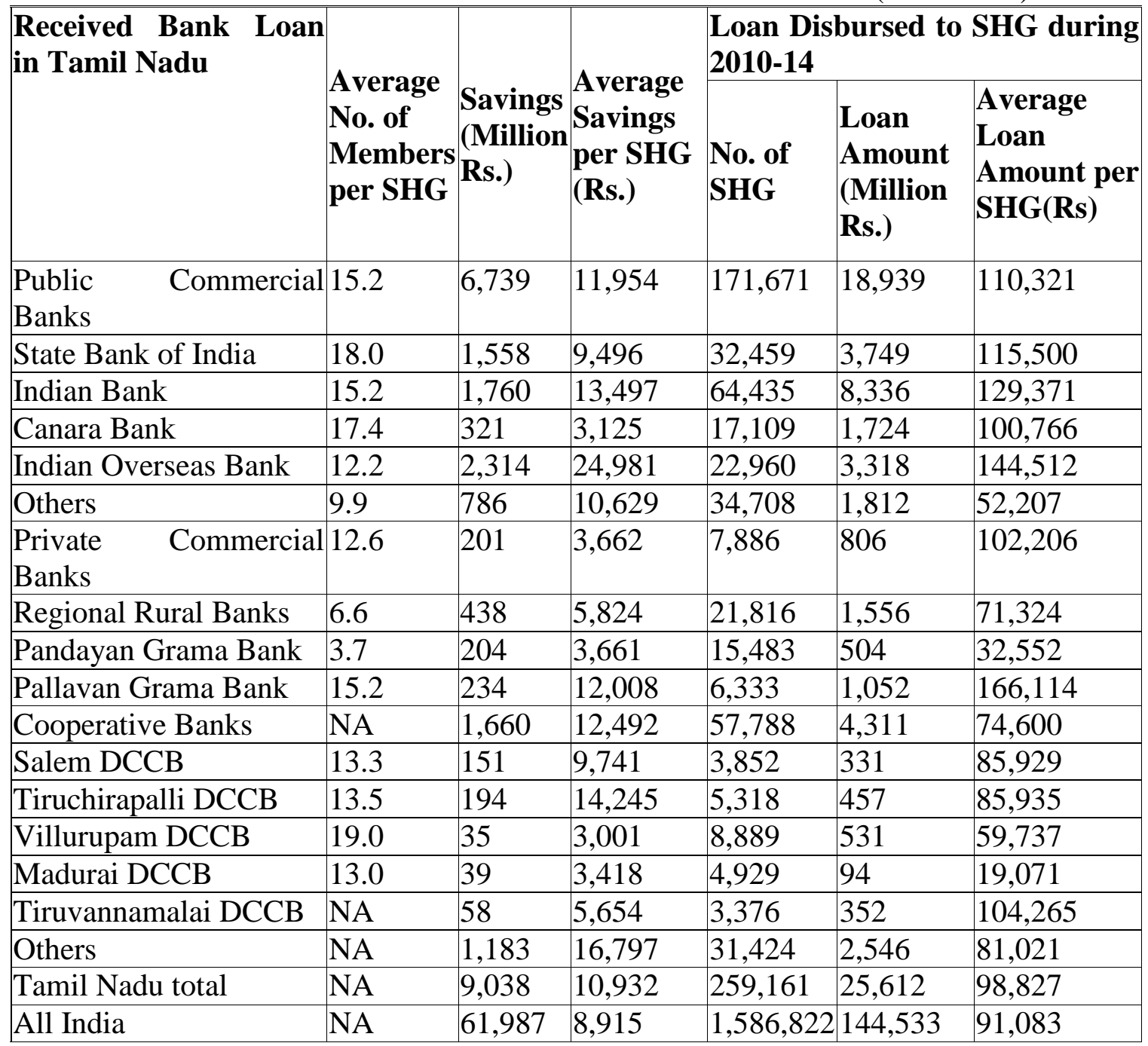

Source: NABARD [2015].Note: DCCB means District Central Cooperative Bank.

As soon as a capital is formed, for availing or providing loans to the needy of SHG members certain steps are taken. The formation of the capital could be carried out even by habit of thrift or small savings which is a fundamental prerequisite for the members and that will assist the formation of a sound common fund for the successful functioning of the SHGs. NABARD 
recognized the potential of these groups and realized that they are constrained only due to the meagerness of their financial resources. It was started as a pilot project in 1992 and has come a long way since then. As of 2012- 2015, there were 7.4 million SHGs under this scheme covering over 10 crore households with savings balance of over Rs.39,375 About 49 lakh of these SHGs have also accessed bank credit and have over Rs 51,545 crore as outstanding credit from the banking system.

\section{Impact of Self-Help Groups on Socio- Economic Development of poor household women and economically weaker section society}

\section{1) Micro- Financing benefit for rural poor households}

Self-help has aimed at enhancing profitability for rural people. The low economic growth of this country was perceived to be due to lack of capital resources, especially in rural areas. A vicious cycle of low capital, low productivity, low incomes, low savings and weak capital base was perceived to be operating perpetuating a permanent poverty syndrome. Therefore, cheap rural credit policies like micro financing SHGs were designed to provide rural poor with access to adequate capital. Microfinance through SHG has become a ladder for the poor to bring them up not only economically but also socially, mentally and attitudinally and above all help them break through the stronghold of exploitative money lenders.

\section{2) Bank - SHG linkage}

In this type of linkage banks provided financial support to SHGs which had grown almost spontaneously without any intervention of any SHPI. The SHGs were initially on the basis of a common activity, Problem and took up thrift and credit activities. The case of such linkages is not very common. In this model, the SHPI have taken the role of a financial intermediary between the banks and a number of SHGs.

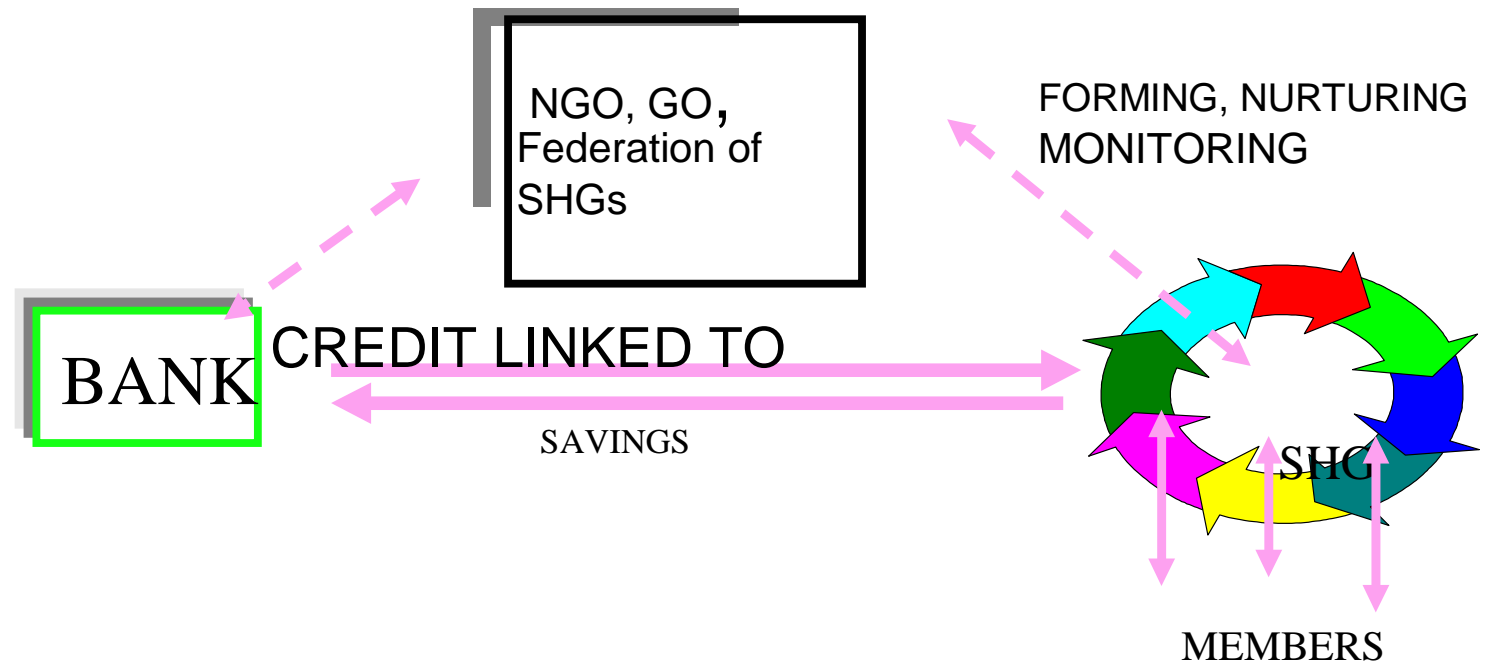

Figure 2: Bank-SHG linkage with active support of SHPI 


\section{3) Economic empowerment}

According to the report by National Commission for Women (NCW) - (Status of women 2011), in India, women work for longer hours than men do. The proportion of unpaid activities to the total activities is $51 \%$ for females as compared to only $33 \%$ for males. Over and above this unpaid work, they have the responsibilities of caring for household which involves cooking, cleaning, fetching water and fuel, collecting fodder for the cattle, protecting the environment and providing voluntary assistance to vulnerable and disadvantaged individuals in the family. This shows that though there is still a long journey ahead towards women empowerment. Women's are save small amount of money regularly and mutually agree to contribute a common fund. But this does not fulfill all their needs. Indebtedness has become the hallmark of the rural life.

\section{4) Social empowerment}

The social empowerment means that the woman should get an important place in her family and society, and should have a right to enable her to make use of available resources. It has resulted in developing self-confidence, self-esteem and self-respect also. And uplift the living conditions of the poor household women's. As the woman has now increased presence in banks, Gram Panchayats, various Government committees etc., her social status is seen somewhat elevated. The social impact of the SHG program increased involvement in Decision-making, awareness about various programs and organizations, increased access to such organizations, increased expenditure on Health and Marriage events, there is a Change in the attitude of male members of the families, now they are convinced about the concept of SHG and encourage women to participate in the meetings and women reported that they have savings in their name and it gives them confidence and increased self-respect.

\section{5) Saving and Financial Decision Making}

One of the primary benefits of participation in a SHG is the opportunity to save regularly, access formal savings institutions and participate in the management of these savings. They save regularly, have their own bank accounts and make deposits into these accounts. SHG is having a good impact on members, in their ability to save their hard earned money.

\section{6) Access to credit}

A corollary of participation in SHGs is an improvement in a woman's access to credit. Since the project is perhaps too early in its implementation to directly improve women's access to credit. The financial mobility due to participation in the SHG has led to an improvement in the quality of life, according to some of the successful groups. Overall, many families were able to address their basic needs better than before. Some of NGOs reports have shown that the record on the repayment of loans by women was often better than that of men, and that women were also more likely to spend the income earned, on their families, leading to improved health and nutrition of the poor population and for improving the quality of their lives. 


\section{7) Employment}

The implementation of SHG has generated Self-employment opportunities for the rural poor. The progress of the program since inception assisted in formation of 35.7 lakh SHGs; assisted 1.24 Cr. Swarozgaris in establishing their own micro-enterprises. The Government of India released Rs.11, 486 Crore under the program; bank credit mobilization is Rs.19, 017; Total subsidy provided is Rs.9, $318 \mathrm{Cr}$. The program helped many participants in improving their economic conditions. Another good accomplishment of the program is that it has adopted the SHG strategy.

\section{8) Challenge to target the real poor and vulnerable sections}

A comprehensive study by BIRD, 2007 on coverage of SCs/ STs in SGSY, which covered 10,848 Swarozgaris and non-Swarozgaris (control sample), pointed out exclusion of SCs and STs in the following ways and for the following reasons. Physical exclusion - by not being accepted as group members, Financial exclusion by denial of their due share either by group leaders or by implementing bank or block officials, Exclusion because they are already covered under some state government sponsored programs (often implemented by state (ST/ SC corporations) and in many cases are already defaulters of bank loans (BIRD, 2007).

\section{CONCLUSION}

This is a very significant indicator of impact. Self Help Group is an important tool which helps the rural women to acquire power for their self-supportive life. SHG Programme clearly plays a central role in the lives of the poor. Empowering women is not just for meeting their economic needs but also more holistic social development. There is evidence of increased household income. Standard of living for the program participants have increased and also the food security is much more for the program clients. Microfinance is playing a significant role in alleviate poverty and rural development. Since women are the sole family caretaker, proper emphasis should be given to the rural women and for empowering the rural women finance is required. Microfinance to the rural SHGs is a way to raise the income level and improve the living standards and economic independence of the rural women. The impact on their lives is not just an economic one -gaining more self-confidence is often a more lasting achievement that forms the basis for social and economic improvements.

\section{REFERENCES}

[1] Ackerly, B.A. (1995). "Testing the Tools of Development: Credit Programs, Loan Involvement and Women's Empowerment”, IDS bulletin, 26 (3), 56-68.

[2] Ang, M.H. (2004). "Empowering the poor through microcredit", Entrepreneurship and Innovation Management, 4(5), 485-494.

[3] Banerjee, T. (2009). "Economic impact of Self-Help Groups- A case study”, Journal of Rural Development, 28 (4), $451-467$.

[4] Das S K and Bhowal A (2013). Impact of Micro Finance: Perceptions Of Direct Stakeholders Of Self-Help Groups. Journal of Business and Economics Research, 2 (6), 142-157. 
[5] Dasgupta, Rajaram (2005). "Micro-finance in India, Empirical Evidence, Alternative Model and policy Imperatives, " Economic and political weekly, 9 March

[6] Galab S and Rao CN (2003). Women's Self-Help Groups, Poverty Alleviation And Employment. Economic and Political Weekly. 38(12): 1278-83

[7] Golden, A. P. S. A. R. MOBILE SUBSCRIBERS'SATISFACTION TOWARDS SERVICE QUALITY IN TUTICORIN DIST, International Journal of Research - Granthaalayah.

[8] Golden, S. A. R. (2015). Regional Imbalance affecting quality of e-banking services with special reference to Tuticorin District-An Analysis. International Journal of Research, 2(3), 788-798.

[9] Kumaran KP (2002). Role of Self Help Groups in Promoting Micro Enterprise through Micro Credit: An Empirical. Journal of Rural Development, 21 (2): 231-250.

[10] Manimekalai (2004). “Gross Root Women Entrepreneurship through SHGs, ” Peninsular Economist, Vol XII, No2, Pp: 181-187.

[11] Mansuri, B.B. (2010). "Micro Finance through Self- Help Group-A case study of Bank linkage Programme of NABARD”, APJRBM, Volume I, Issue 3, December, P-3.

[12] Narayan, D. (ed.) (2005). Measuring Empowerment: Cross-Disciplinary Perspectives, Washington DC: World Bank.

[13] Premchander, Smita, and Prameela V (2007). Empowering Women through Microfinance: A Policy and Programme Review. Delhi: CARE India.

[14] Regi, S. B., \& Golden, S. A. R. (2014). Customer Preference Towards Innovative Banking Practices Available In State Bank Of India At Palayamkottai. Sankhya International Journal Of Management And Technology, 3 (11 (A)), 31, 33.

[15] Sinha, F. (2005). 'Access, Use and Contribution of Microfinance in India: Findings from a National Study', Economic and Political Weekly, 40(17). 